\title{
Polish DeAdlock: Between Liberal AND Right-Wing ANTI-COMMUNISM ${ }^{1}$
}

\author{
JAKUB MAJMUREK
}

Let me narrow down the scope of the answer for the questions posed by the editors of "Theoretical Practice" to a specific place and time: Poland after 1989. In Poland after 1989, we had essentially two forms of anti-communism: a liberal and a right-wing one. The first dominated the 1990s; the second came into force after 2015. Each of these two anticommunisms was aiming its anti-communist bludgeon at different targets.

The basic figure of liberal anti-communism was homo sovieticus - the enslaved subjectivity created by the communist regime, always ready to choose a full belly over freedom, security above personal dignity. The representatives of the liberal elites labelled as such all the subjectivities (both individual and collective), that stood in the way of the transformation that they designed. Homo sovieticus was supposed to be incapable of becoming a citizen of liberal democracy as a subject rationally operating within the new market conditions. The label and accompanying discursive practices were supposed to stigmatize these groups that were losing (at least in the short-term) in consequence of the changes that happened during the 1990s (employees of shut-down factories, strong trade unions of the public sector, employees of PGR 2 , etc.), taking away the public legitimacy of the demands they made.

\footnotetext{
1 The title comes from the editors.

2 PGR (pol. Państwowe Gospodarstwo Rolne) - State-owned Agricultural Enterprise, a form of collectivized agricultural enterprise operating in Poland during the real socialist period (until 1993).
} 
Liberal anti-communism looked at the People's Republic of Poland as a world set on its head, where the "natural" socio-economic rights (with the market economy and private ownership at its forefront) were reversed. Poland after 1989 - proponents of this type of anticommunism argued - had to be put back on its feet, without looking at the relics of the former system. The paradox of this discourse lay in the fact that with the aim to establish conditions in Poland that were "normal as in the West", it attacked those institutions which in post-war Western Europe constituted the backbone of what we call the "golden age of capitalism": strong trade unions, the coexistence of public and private property, and a social security network. Also in Western Europe, these institutions have been in the heat of political attack since the mid-1980s - Polish liberal anti-communism in the 1990s can be seen as a local form of the global attack on a post-war, state-controlled form of capitalism highly focused within the borders of the nation-state.

Right-wing anticommunism also perceives communism as "a world set on its head", but it is not limiting this claim to the sphere of economics and property relations only. Communism is seen here as a period of foreign occupation and national enslavement, something that Poles were forced into from outside - one cannot imagine a statue of an honest Polish communist on such ground.

Speaking of what happened in Poland after 1944, this discourse often uses the figure of "war of races" - as Michel Foucault understands it in his analysis of journalism from the period of the English Revolution. Columnists on the side of Parliament presented the following narrative: the conquest by the Normans destroyed the Anglo-Saxon political institutions and imposed on England a foreign, monarchical system. Parliament, fighting for power with the king, liberated the Anglo-Saxons from the centuries of the Norman yoke. In conservativenational anti-communism, the place of Norman conquest is located during the years of 19441945. The Communists, like the Norman knights in $11^{\text {th }}$ century England, enslaved the Poles. The so-called "cursed soldiers", an anti-communist, radical nationalist underground, fought against them, but they lost. The struggle of the "third generation of the Home Army with the third generation of Security Office (UB)" is still going on.

This discourse not only aims to completely remove the legitimacy of the PRL, but also that of the Third Polish Republic. The purpose of this anti-communism is to completely change the elite structure, giving space for those focused on the current right. The assumption is that for the present, the elites are still false elites attached to the Soviet past and connections. The Third Polish Republic seemingly removed the communists from power, but only to preserve their actual rule. How this tactic of delegitimisation operates can be seen at its best on the occasion of disputes over judicial reform that have been going on in recent years. Especially symptomatic was the monologue of Michał Rachon, one of the leading Polish public TV journalists from 2017: “Communist courts and security services murdered tens of thousands 
of Polish heroes who fought against the occupant. (...) The same people in 1989 suddenly began to call themselves 'independent judges' and became the guards of the Round Table Agreement. (...) Their children were promoted in the structures of the lawless system for 30 years of the Third Polish Republic".

Right-wing anti-communism goes along with the discourses of cultural wars: the war against "gender ideology", the dictates of political correctness, the Islamization of Europe. Right-wing anti-communism in contemporary liberal consensus in the West (marital equality, rights of trans people, rights of non-white people) sees the manifestation of the dictatorship of "Leftism" and its main ideological tool, "cultural Marxism" as an evil twin of the Polish communist dictatorship, and in some respects a much more dangerous one. On this plane, the goals of right-wing anti-communism go even further: it is about defending the conservative Polish status quo, blocking cultural change, and delegitimising all symbols associated, however remotely, with discourses and emancipation practices. This is often connected with the rehabilitation, or at least the relativisation of fascism, such as generals like Pinochet or Franco - "the defender of Europe against communism".

Right-wing anticommunism has no single figure that gathers its discourses, like homo sovieticus. The closest to this is probably the figure of "Major Bauman" - as the right-wing press calls an outstanding sociologist, Zygmunt Bauman. "Major Bauman" brings together the narrative of the "war of races", and the Soviet conquest, the figure of the elite of the Third Polish Republic and the modern Western left, and as such is the ideal object of attacks for right-wing anti-communism.

How to oppose anti-communisms in contemporary Poland? Liberal anti-communism today is, in my opinion, in decline, even if its copies sometimes haunt us in the language of the liberal opposition - for example, stigmatising the beneficiaries of the $500+$ social program. However, I believe that although the practices of stigmatisation of economically weaker groups will not disappear, anti-communism will play a decreasing role here. These groups need better self-organisation and representation, regardless of the dispute over communism.

How to disarm the right-wing anti-communism that has become dominant today? What is needed is a politics of remembrance that would take the two following forms - first, the decriminalisation of communism. The stakes should be the presentation of communism not as a foreign idea, attacking Poland almost from the cosmos, but as one of the many ideological choices that individuals made in the history of the twentieth century. Even if today it seems completely wrong, it at least deserves understanding. Secondly, it is necessary to fight back against the lies in the history of the PRL. It was the Polish People's Republic that created Polish society as we know it today. The narrative about "Soviet occupation" and the unbreakable disagrees with the memory of most of the Polish families. Although it is difficult to deny Stalin's terror and impossible to defend it, the PRL is a series of other experiences: migration from the 
countryside to the cities, agricultural reform, class advances, industrialisation, literacy. The dependent and authoritarian state realised the postulates of the people's or workers' movement.

If Poland of the $21^{\text {st }}$ century is to create a reasonable politics for itself, it cannot be based on a false awareness of what are the origins of the present state of their country and its people. We are not from the "cursed soldiers", but from the PRL movement from the countryside to the cities, schools built to celebrate the one-thousandth anniversary, and the expansion of the intelligentsia, which took place during the rule of that system. The more such a memory becomes hegemonic, the less space for all the anti-communisms sketched above.

Jakub Majmurek - film scholar, essayist, and publicist. Active mostly as a film critic, but he also writes about literature and visual arts. A graduate of the film studies in Kraków and Institute of Political and International Studies at the Jagiellonian University, he also studied at the School of Social Sciences at the IFiS PAN in Warsaw. His articles were published in, among others, Tygodnik Powszechny, Gazeta Wyborcza, Oko.press, Aspen Review. Co-author and editor of many book in the field of film studies, most recently of Kino-sztuka: Zwrot kinematograficzny w polskiej sztuce wspótczesnej (Cine-art: The Cinematographic Turn in Contemporary Polish Art, together with Lukasz Ronduda).

Citation: Majmurek, Jakub. 2019. "Polish Deadlock: Between Liberal and Right-Wing Anti-Communism” Praktyka Teoretyczna 1(31): 174-177.

DOI: $10.14746 /$ prt.2019.1.10 